\title{
The Situation of Elderly Cancer Patients
}

Demographic changes with a continuous increase in life expectancy will lead to a substantial increase in the frequency of malignant diseases in many Western nations. Thus, in the near future, cancer will be the leading cause of mortality in these countries. Contrasting to their demographic and economic impact, elderly cancer patients do not yet play a major role in either geriatric medicine or clinical hematology and oncology. Treatment of elderly cancer patients is frequently associated with several misunderstandings: Some physicians still think that elderly cancer patients will not profit at all or less frequently from the use of standard chemotherapy regimens than younger cancer patients. It is also believed that chemotherapy in elderly patients is associated with significant toxicity and a decrease in life quality. Frequently no distinction between age as a risk factor for cancer prognosis on its own and age-associated diseases and functional deficits is made. Although the number of prospective trials in elderly cancer patients is very limited [1], meta-analyses have demonstrated that most chemotherapy agents can be applied in elderly patients, taking into account specific organ functions that may necessitate dose modifications. Dosing guidelines are based on renal and hepatic parameters but not on the chronological age of the patient [2].

The psychological and social conditions framing the context of treatment for malignant diseases in elderly patients do play a significant role for the prognosis and treatment outcome. Validated geriatric assessment instruments have been developed to identify these specific factors. Assessment should be followed by systematic interventions and effective symptom control $[3,4]$. Supporting patients in their activities of daily life (ADL) and in their motor and cognitive functions is clearly related to the success of anticancer treatment in elderly patients. The psychosocial background of elderly cancer patients is also a significant determinator of the patient's wish of being treated for malignancies and for the quality of life during the treatment process.

Due to the overall importance of 'Geriatric oncology topics', more research will hopefully be directed into this field in the future. The review by Korneck in this issue of ONKOLOGIE can be recommended for reading to get involved into this topic. While in the USA active study groups have started years ago to cooperate in the field of geriatric oncology with leading experts working at the University of Florida in Tampa, the cooperation between oncology and geriatrics in Germany is still not sufficiently developed. Interdisciplinary training and common understanding is important for diagnosis, therapeutic decisions and for achieving therapy goals in elderly cancer patients [5-7]. Thus, a transfer of knowledge between geriatric medicine and clinical hematology/oncology is important [8]. Despite the trend towards an increasing number of 'treatment guidelines' for several specific situations in oncology, very few studies have given the scientific background for treatment recommendations in elderly patients $[9,10]$.

This situation has been the background to form an interdisciplinary group on 'Geriatric Oncology' which has been established by the German Society of Hematology and Oncology (DGHO) and the German Society for Geriatric Medicine (DGG) in 1999/2000. The tasks for this working group are as follows:

(1) Analysis and interpretation of currently available data on treatment results in elderly cancer patients.

(2) Definition of deficits in geriatric oncology and identification of the necessary research questions.

(3) Developing recommendations for future clinical oncology studies in geriatric patients in association with the German Cancer Society.

(4) Development and recommendation of validated geriatric assessment instruments for both routine use in elderly cancer patients and for future clinical studies in this field.

(5) Information and teaching of the specific aspects of geriatric oncology to physicians in both fields. The latter point has been specifically achieved by a symposium of the 'Wilsede School for Oncology and Hematology' in the spring of this year, and future activities are already planned.

It is our hope that the number of physicians with experience in geriatric oncology will significantly increase in the near future. Currently, elderly cancer patients are often inadequately diagnosed and treated or not treated at all. If we want to be successful in promoting effective therapy for our elderly patients we need to communicate the available data about the efficacy of cancer treatment in this patient population. This will also help in the future to enter the unavoidable discussion about the use of economic resources in cancer therapy and in medicine in general $[11,12]$. The best approach to achieve this goal will again need controlled prospective studies about diagnosis and therapy in the elderly cancer population.

C. Bokemeyer, Tübingen; G. Kolb, Lingen

Für den Arbeitskreis «Geriatrische Onkologie» der DGHO/DGG: C. Bokemeyer, Tübingen; C. Friedrich, Bochum; K.-P. Hellriegel, Berlin; F. Honecker, Tübingen; O. Kloke, Recklinghausen; K.-M. Koeppen, Berlin; T. H. Köhne, Dresden; G. Kolb, Lingen (Ems); G. Krüger, Gelsenkirchen; J. Meran, Wien; L. Pientka, Bochum; H. Schmidt, Hameln; S. Schmitz, Köln; E. Späth-Schwalbe, Berlin; U. Wedding, Jena.

\begin{tabular}{ll}
\hline KARGER & $\oplus$ 2001 S. Karger GmbH, Freiburg \\
$\begin{array}{l}\text { Fax }+497614520714 \\
\begin{array}{l}\text { E-mail Information@Karger.de } \\
\text { www.karger.com }\end{array}\end{array}$ & $\begin{array}{l}\text { Accessible online at: } \\
\text { www.karger.com/journals/onk }\end{array}$
\end{tabular}

\section{KARGER}

www.karger.com

\section{Accessible online at:
www.karger.com/journals/onk}




\section{References}

1 Hutchins LF, Unger JM, Crowley JJ, Coltmann CA Albain KS: Underrepresentation of patients 65 years of age or older in cancer-treatment trials. New Engl J Med 1999;341:2061-2067.

2 Mayer F, Lipp H-P, Kanz L, Bokemeyer C: Supportive Therapie und der Einsatz zytostatischer Substanzen bei geriatrisch-onkologischen Patienten. Eur J Geriatrics 2000;2:188-197.

3 Balducci L: Geriatric oncology: Challenges for the new century. Cancer 2000;1741-1754.

4 Extermann M, Balducci L, Lyman GH: What threshold for adjuvant therapy in older breast cancer patients? J Clin Oncol 2000;18:1709-1717.
5 Grilli R, Minozzi S, Tinazzi A, Labianca R, Sheldon TA, Liberati A: Do specialists do it better? The impact of specialization on the processes and outcomes of care for cancer patients. Ann Oncol 1998;9: 365-374.

6 Kennedy BJ: Aging and cancer: Geriatric oncology keynote address to the Integrating Geriatrics into Oncology Education. Cancer 1997:80:1270-1272.

7 Kleeberg UR: Ergebnisqualität in der internistischen Onkologie. Onkologe 1998;4:414-419.

8 Reuben DB: Geriatric assessment in oncology. Cancer 1997;80:1311-1316.
9 Cohen HJ: The Oncology Geriatric Education Retreat: Commentary and conclusions. Cancer 1997;80:1354-1356.

10 Honecker F, Wedding U, Kolb G, Bokemeyer C: Chemotherapie des kolorektalen Karzinoms welche Therapie ist bei älteren Patienten gerechtfertigt? Onkologie 2001;24:87-94.

11 Bailes JS: Health care economics of cancer in the elderly. Cancer 1997;80:1348-1350.

12 Jorke D: Ethische Dimension der geriatrischen Onkologie. Onkologe 1998;4:61-65. 